\title{
Hydrochemistry of the Hot Springs in Western Sichuan Province Related to the Wenchuan $M_{S}$ 8.0 Earthquake
}

\author{
Zhi Chen, ${ }^{1,2}$ Jianguo Du, ${ }^{2}$ Xiaocheng Zhou, ${ }^{2}$ Li Yi, ${ }^{2}$ Lei Liu, ${ }^{2}$ Chao Xie, ${ }^{2}$ \\ Yueju Cui, ${ }^{2}$ and Ying $\mathrm{Li}^{2}$ \\ ${ }^{1}$ School of Earth and Space Sciences, University of Science and Technology of China, Hefei 230026, China \\ ${ }^{2}$ CEA Key Laboratory of Earthquake Prediction (Institute of Earthquake Science), China Earthquake Administration, \\ Beijing 100036, China \\ Correspondence should be addressed to Jianguo Du; jianguodu@hotmail.com
}

Received 1 January 2014; Accepted 5 February 2014; Published 5 May 2014

Academic Editors: J. Glodny, P. C. McGuire, and L. Tosi

Copyright (C) 2014 Zhi Chen et al. This is an open access article distributed under the Creative Commons Attribution License, which permits unrestricted use, distribution, and reproduction in any medium, provided the original work is properly cited.

\begin{abstract}
Hydrogeochemistry of 32 hot springs in the western Sichuan Province after the Wenchuan $M_{S} 8.0$ earthquake was investigated by analyzing the concentrations of cation and anion and the isotopic compositions of hydrogen and oxygen. The water samples of the hot springs were collected four times from June 2008 to April 2010. Hydrogeochemical data indicated the water samples can be classified into 9 chemical types. Values of $\delta \mathrm{D}$ and $\delta^{18} \mathrm{O}$ indicated that the spring waters were mainly derived from meteoric precipitation and affected by water-rock interaction and mixture of deep fluids. Concentrations of $\mathrm{K}^{+}$and $\mathrm{SO}_{4}{ }^{-}$of the samples from the Kangding district exhibited evident increases before the Wenchuan earthquake, indicating more supplement of deep fluids under the increase of tectonic stress. The chemical and isotopic variations of the water samples from the area closer to the epicenter area can be attributed to variation of regional stress field when the aftershock activities became weak.
\end{abstract}

\section{Introduction}

Great earthquakes usually associate with the physicalchemical variations of groundwater and hot springs. The short-term hydrogeochemical precursors for earthquake [1$4]$, co-seismic response of hydrochemistry $[5,6]$ and postseismic geochemical and isotopic changes of hot springs have been reported [7-12].

The observed geochemical anomalies related to earthquakes are usually attributed to the alteration of groundwater in the circulating system under the action of increasing crustal stress before and after earthquakes $[6,7,13$, 14]. For understanding the hydrogeochemical anomalies related to earthquakes, some genetic mechanism models have been proposed, such as increased solubility of rocks under increased pressure and release of ions from rocks into water [15], pore collapse with fluids expulsion [8], the water-rock interactions at the enhanced reactive surfaces [16], aquifers rupture with mixing of different fluids [6] and expulsion of deep fluids by tectonic pumping [1].
Hydrogeochemical survey of hot springs in western Sichuan before the $M_{S} 8.0$ Wenchuan earthquake mainly focused on the origin of waters, the pollutions, the chemical classifications and the heat reservoirs in the sites surrounding Kangding county [17-25].

The $M_{S} 8.0$ earthquake occurred in Wenchuan county, Sichuan province, Southwest China on 12 May, 2008, following by hundreds of aftershocks with magnitudes higher than 3.0.

In order to investigate the hydrogeochemical characteristics of the springs related to the seismic activities, the hydrogeochemical survey of 32 hot springs in the western Sichuan were performed four times from June 2008 to April 2010.

\section{Geological Setting}

The investigated area is located at the eastern margin of the Tibetan Plateau, in which there are four major fault zones 


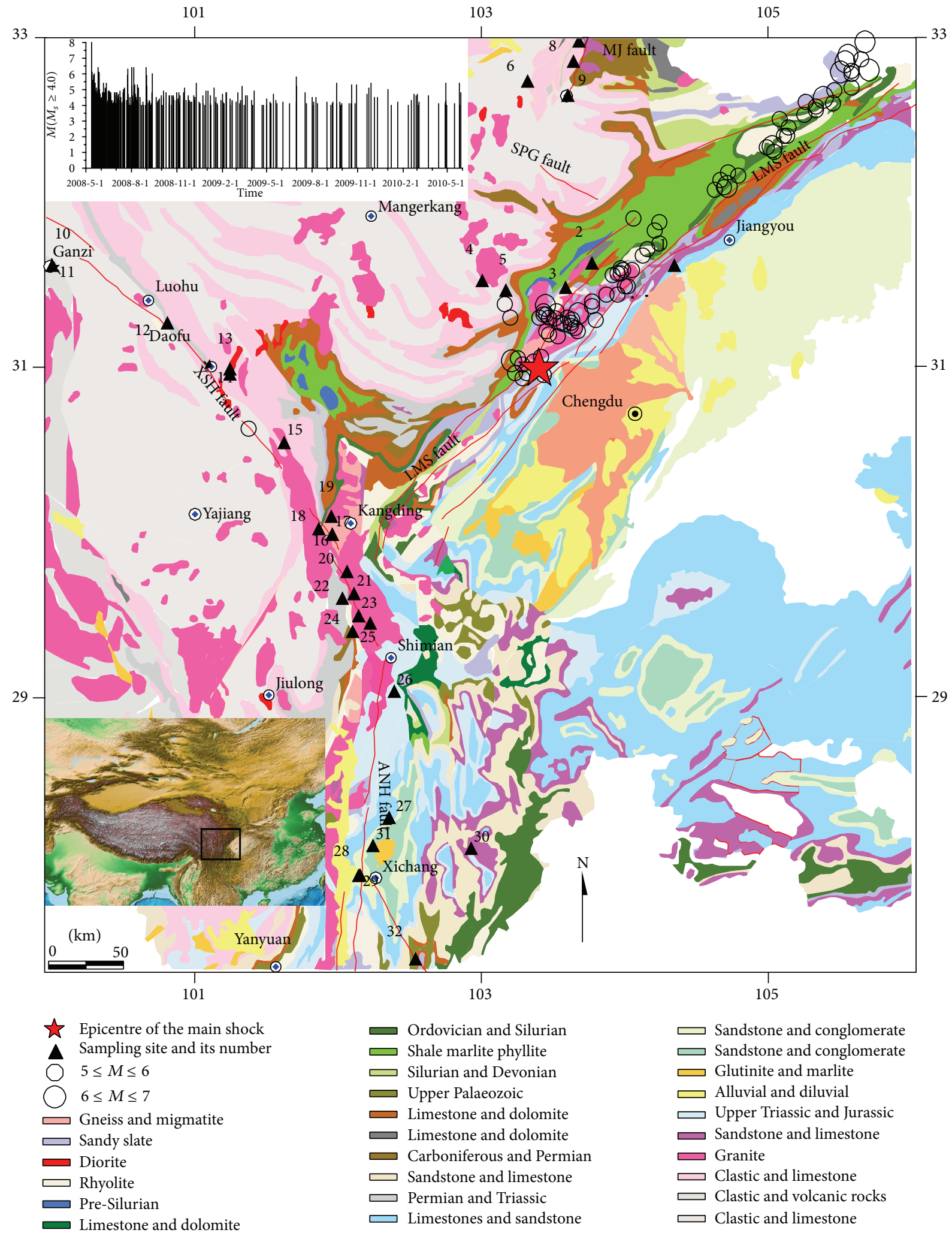

FIGURE 1: Schematic map of geology in western Sichuan Province, showing the sample locations, and earthquake epicenters, the insert figure is time-magnitude plot for aftershocks with $M_{S} \geq 4$, red lines are active faults. 
named as Minjiang fault (MJF), Longmenshan fault (LMSF), Xianshuihe fault (XSHF) and Anninghe fault (ANHF) zones (Figure 1) where earthquakes frequently occurred [26].Triassic littoral-neritic clastic rocks interbeded with carbonate and intrusive granite are exposed in the west of the LMSF and ANHF zones, but the strata from Late Paleozoic to Cenozoic are widespread exposed in the LMSF and ANHF zones and on the east of the fault zones, and granite is found in the intersection of the LMSF, XSHF and ANHF zones [27-30]. The fault zones act as the important passage for upward migration of thermal fluids from the deep earth, which is indicated by distribution of many hot springs in the MJF, LMSF, XSHF and ANHF zones (Figure 1). Historically, a number of great earthquakes $\left(M_{S}>7.0\right)$ have occurred in the investigated area since 1800 . For instance, the $1850 M_{S}$ 7.5 Xichang earthquake occurred in the ANHF zone, two $M_{S}$ 7.2 earthquakes of 16 and 23 August 1976 in the MJF zone, the $M_{S} 7.5$ one of 25 August 1933 in the LMSF zone, and the $M_{S} 7.5$ one of 1955 and the $M_{S} 7.9$ one of 1973 in the XSHF zone [12]. The $M_{S} 8.0$ Wenchuan earthquake resulted in a $285 \mathrm{~km}$ surface rupture zone along the pre-existing YingxiuBeichuan, Guanxian-Anxian and Qingchuan faults, with the maximum vertical surface offset of about $6.2 \mathrm{~m}$ [31].

\section{Methods}

Water samples were repeatedly collected four times (in June and October 2008, June 2009, and April 2010) at 32 sites of spas, wells, and springs (Figure 1) in the MJF, LMSF, XSHF, and ANHF zones. The samples were sealed and stored in $500 \mathrm{~mL}$ glass bottles. The values of temperature were measured with a digital thermometer with an error of $\pm 1 \%$ in the field. Isotopic compositions of $\delta \mathrm{D}$ and $\delta^{18} \mathrm{O}$ were measured with a Picarro L1102 mass spectrometer in the Laboratory of Gas Geochemistry, Institute of Geology and Geophysics, Chinese Academy of Sciences in Lanzhou, and the errors are $0.5 \%$ for $\delta \mathrm{D}$ and $0.1 \%$ for $\delta^{18} \mathrm{O}$, respectively. The concentrations of cations $\left(\mathrm{K}^{+}, \mathrm{Na}^{+}, \mathrm{Mg}^{2+}\right.$, and $\left.\mathrm{Ca}^{2+}\right)$ and anions $\left(\mathrm{F}^{-}, \mathrm{Cl}^{-}, \mathrm{Br}^{-}, \mathrm{NO}_{3}{ }^{-}\right.$, and $\left.\mathrm{SO}_{4}{ }^{2-}\right)$ were determined with the Dionex ICS-900 ion chromatography (reproducibility within $\pm 2 \%$ ) that is installed in the Institute of Earthquake Science, China Earthquake Administration. The $\mathrm{CO}_{3}{ }^{2-}$ and $\mathrm{HCO}_{3}{ }^{-}$concentrations were measured by the standard titration procedures with a ZDJ-100 potentiometric titrator (reproducibility within $\pm 2 \%$ ). The ion balance (ib) was calculated according to the following equation [11]:

$$
\mathrm{ib}(\%)=\frac{\sum \text { cations }-\sum \text { anions }}{\left(\sum \text { cations }+\sum \text { anions }\right) \times 0.5} \times 100 \text {. }
$$

\section{Results}

The physicochemical parameters of the 32 springs were listed in Table 1. No water samples were collected from the springs of nos. 2 and 24-26 in June 2008 because the springs were damaged by the Wenchuan earthquake. No samples were collected from the springs nos. 8 and 29 in April 2010 and the spring no. 28 in June 2009 and April 2010 because of the postearthquake reconstruction. The ion balance values of measured chemical data were calculated to be less than $5 \%$ (Table 1).

4.1. Physicochemical Parameters of the Springs in the LMSF Zone. The water samples from in the LMSF zone have $\delta^{18} \mathrm{O}$ and $\delta \mathrm{D}$ values between $-16.34 \%$ and $-6.18 \% 0,-116.65 \%$ and $-61.66 \%$, respectively. The temperatures and TDS ranged from 10.5 to $58.0^{\circ} \mathrm{C}$ and 151.69 to $1569.81 \mathrm{mg} / \mathrm{L}$. The concentrations of $\mathrm{Na}^{+}, \mathrm{Ca}^{2+}$ and $\mathrm{Mg}^{2+}$ varied from 29.82 to $202.49 \mathrm{mg} / \mathrm{L}, 4.74$ to $252.78 \mathrm{mg} / \mathrm{L}$, and 0.80 to $128.73 \mathrm{mg} / \mathrm{L}$, respectively. The concentrations of $\mathrm{Cl}^{-}, \mathrm{SO}_{4}{ }^{2-}$, and $\mathrm{HCO}_{3}{ }^{-}$ varied from 2.31 to $64.74 \mathrm{mg} / \mathrm{L}, 21.33$ to $878.08 \mathrm{mg} / \mathrm{L}$, and 14.63 to $310.70 \mathrm{mg} / \mathrm{L}$ respectively (Table 1 ).

4.2. Physicochemical Parameters of the Springs in the MJF Zone. Fifteen water samples were collected from the sites nos. 6-9 in the MJF zone, of which the $\delta^{18} \mathrm{O}$ and $\delta \mathrm{D}$ were between $-15.34 \%$ and $-13.20 \%,-112.23 \%$ and $-102.20 \%$, the values of temperatures and TDS ranged from 8.8 to $21.7^{\circ} \mathrm{C}$ and 505.34 to $1657.61 \mathrm{mg} / \mathrm{L}$. The concentrations of $\mathrm{Na}^{+}$, $\mathrm{Ca}^{2+}$, and $\mathrm{Mg}^{2+}$ ranged from 8.75 to $25.23 \mathrm{mg} / \mathrm{L}, 49.54$ to $183.57 \mathrm{mg} / \mathrm{L}$, and 23.23 to $183.57 \mathrm{mg} / \mathrm{L}$, and the concentrations of $\mathrm{Cl}^{-}, \mathrm{SO}_{4}{ }^{2-}$, and $\mathrm{HCO}_{3}{ }^{-}$from 0.93 to $10.78 \mathrm{mg} / \mathrm{L}, 3.56$ to $17.78 \mathrm{mg} / \mathrm{L}$, and 313.61 to $1324.27 \mathrm{mg} / \mathrm{L}$ separately (Table 1 ).

4.3. Physicochemical Parameters of the Springs in the XSHF Zone. Sixty-two water samples were collected from the sites nos. $10-25$ in the XSHF zone, of which $\delta^{18} \mathrm{O}$ and $\delta \mathrm{D}$ varied from $-18.84 \%$ o to $-10.04 \%$ and $-141.98 \%$ o to $-78.77 \%$. The values of temperatures and TDS ranged from 27.8 to $83.0^{\circ} \mathrm{C}$ and 427.53 to $2159.43 \mathrm{mg} / \mathrm{L}$, respectively. The concentrations of $\mathrm{Na}^{+}, \mathrm{Ca}^{2+}$, and $\mathrm{Mg}^{2+}$ ranged from 35.14 to $679.23 \mathrm{mg} / \mathrm{L}$, 4.38 to $50.10 \mathrm{mg} / \mathrm{L}$, and 0.12 to $45.71 \mathrm{mg} / \mathrm{L}$, respectively. The concentrations of $\mathrm{Cl}^{-}, \mathrm{SO}_{4}{ }^{2-}$, and $\mathrm{HCO}_{3}{ }^{-}$ranged from 2.35 to $336.16 \mathrm{mg} / \mathrm{L}, 6.56$ to $161.87 \mathrm{mg} / \mathrm{L}$, and 62.48 to $1894.64 \mathrm{mg} / \mathrm{L}$, respectively (Table 1 ).

4.4. Physicochemical Parameters of the Springs in the ANHF Zone. Twenty-four water samples were collected from the sites nos. 26-32 in the ANHF zone, of which the $\delta^{18} \mathrm{O}$ and $\delta \mathrm{D}$ were between $-11.64 \%$ and $-96.10 \%$, $-110.47 \%$ and $-102.20 \%$. The temperatures of the spring waters were between 21.1 and $56.9^{\circ} \mathrm{C}$, the TDS were between 206.70 and $1212.86 \mathrm{mg} / \mathrm{L}$. The concentrations of $\mathrm{Na}^{+}, \mathrm{Ca}^{2+}$, and $\mathrm{Mg}^{2+}$ ranged from 50.17 to $213.50 \mathrm{mg} / \mathrm{L}, 2.00$ to $81.48 \mathrm{mg} / \mathrm{L}$, and 0.00 to $29.43 \mathrm{mg} / \mathrm{L}$, and the concentrations of $\mathrm{Cl}^{-}, \mathrm{SO}_{4}{ }^{2-}$, and $\mathrm{HCO}_{3}{ }^{-}$from 1.91 to $136.74 \mathrm{mg} / \mathrm{L}, 10.94$ to $257.26 \mathrm{mg} / \mathrm{L}$, and 81.95 to $449.06 \mathrm{mg} / \mathrm{L}$, respectively (Table 1 ).

\section{Discussion}

\subsection{Chemical Types of the Waters and Their Origins}

5.1.1. The Chemical Types. The triangular diagrams in Figure 2 illustrated the proportions of the anionic $\left(\mathrm{Cl}^{-}\right.$, $\mathrm{SO}_{4}{ }^{2-}$, and $\left.\mathrm{HCO}_{3}{ }^{-}\right)$and cationic $\left(\mathrm{K}^{+}+\mathrm{Na}^{+}, \mathrm{Mg}^{2+}\right.$, and $\mathrm{Ca}^{2+}$ ) concentrations of the water samples from the 32 


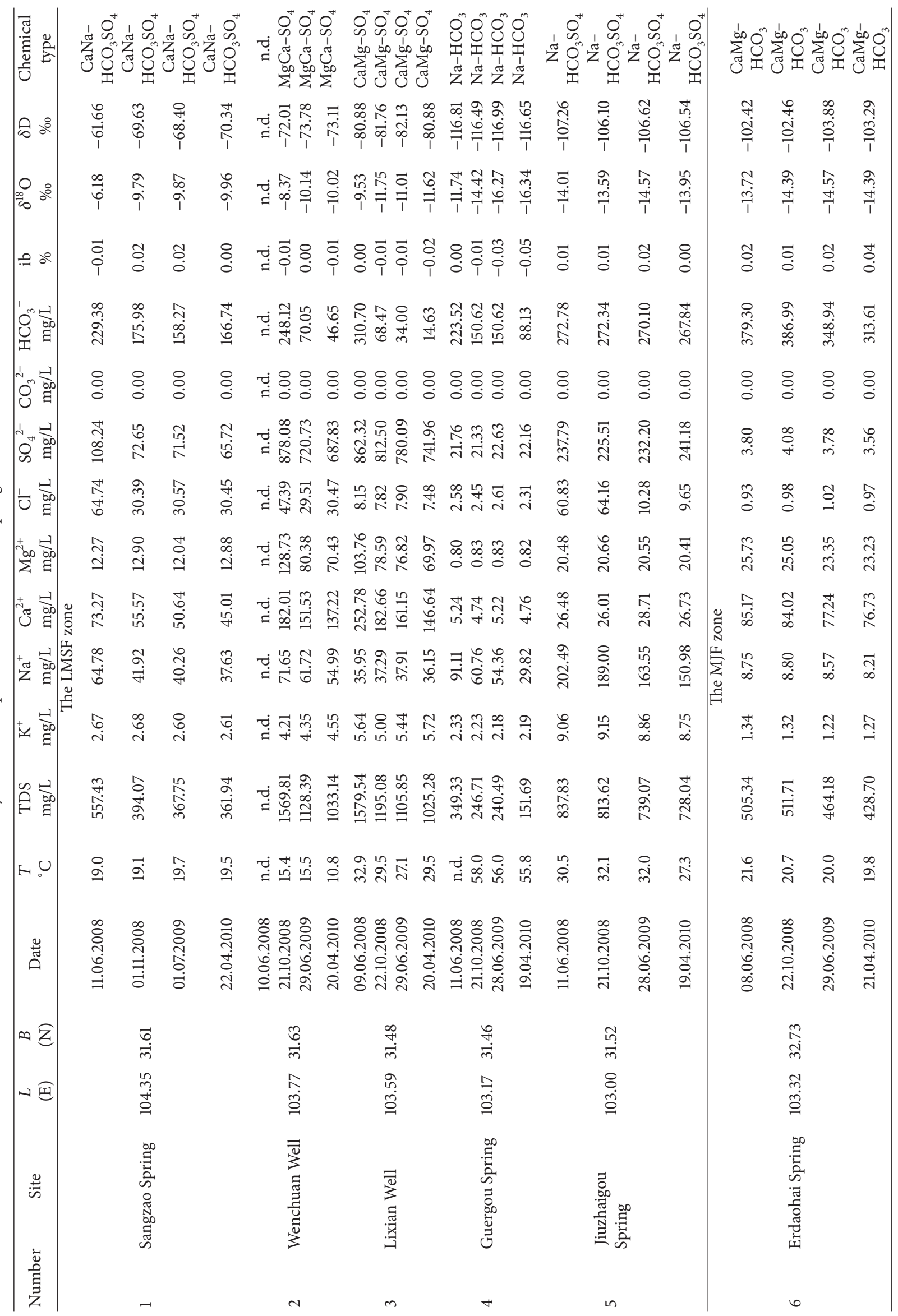




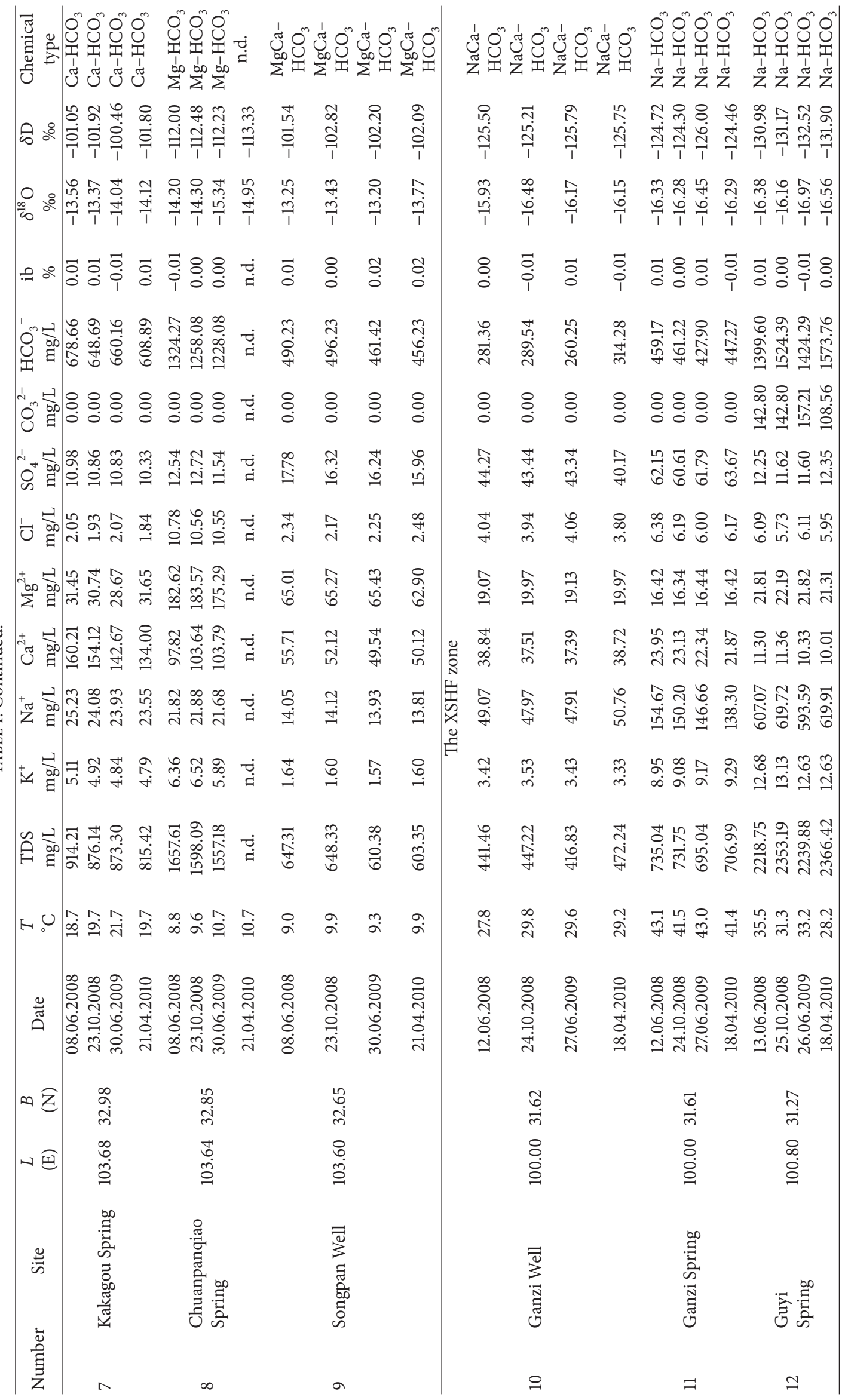




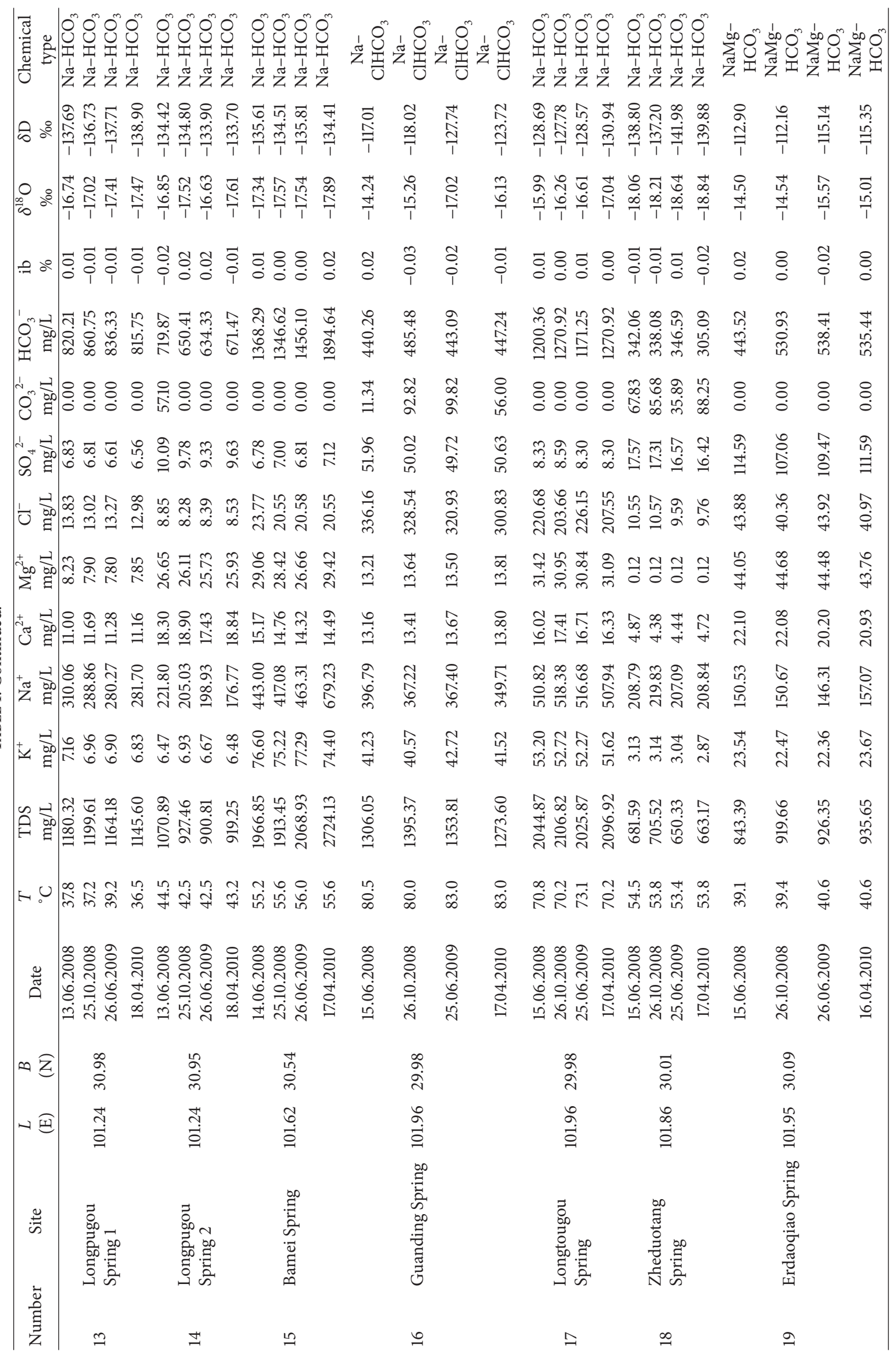




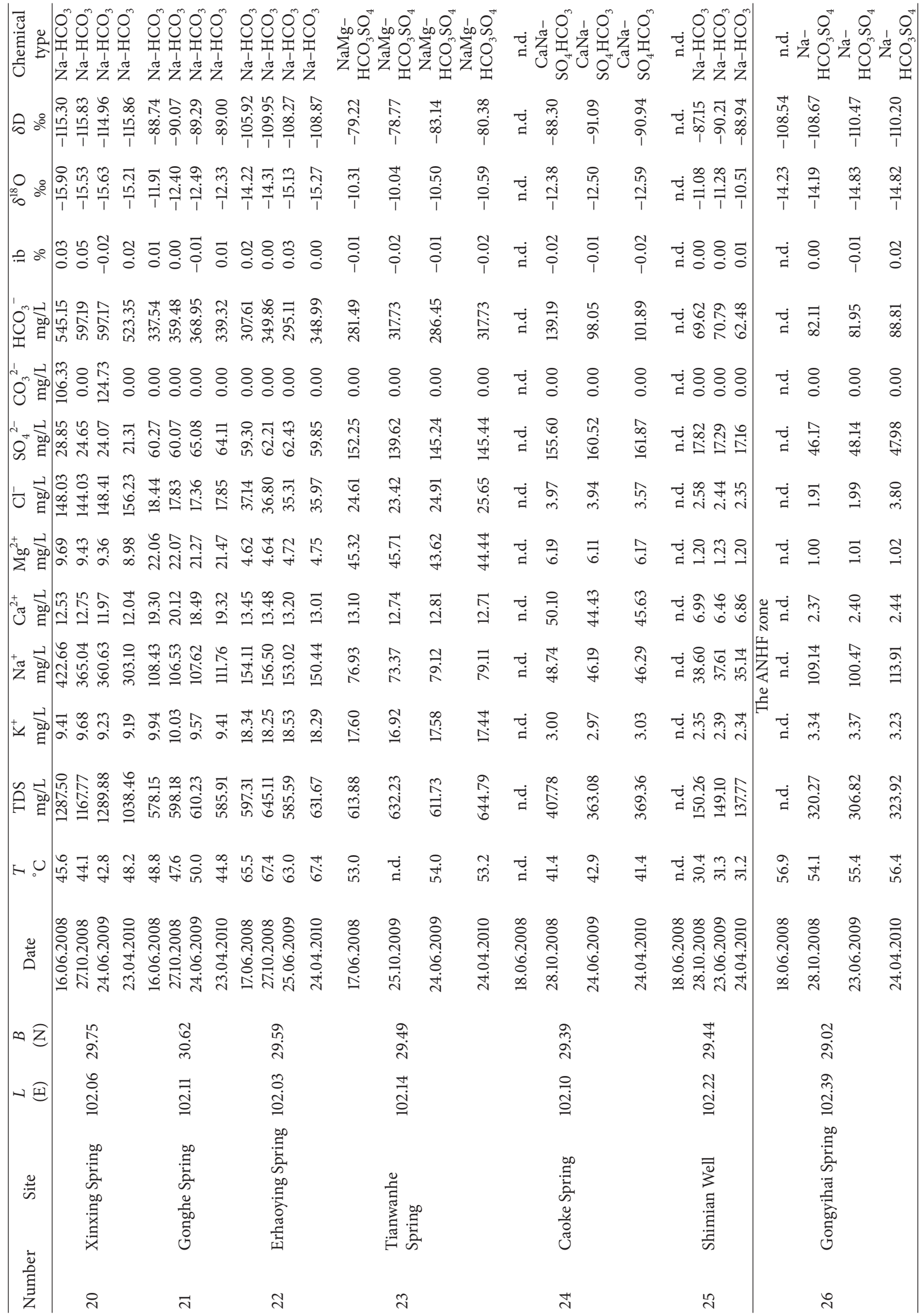




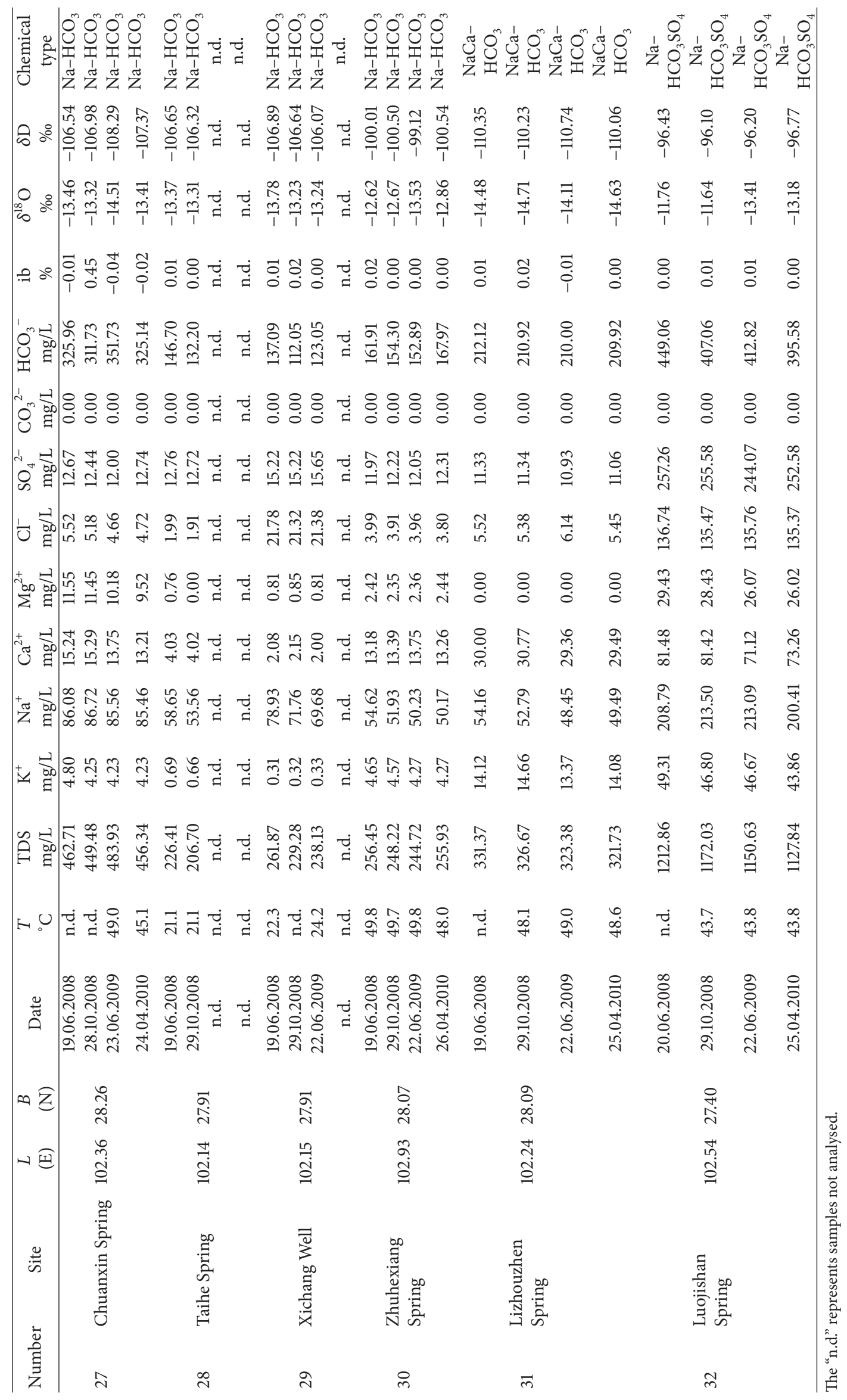




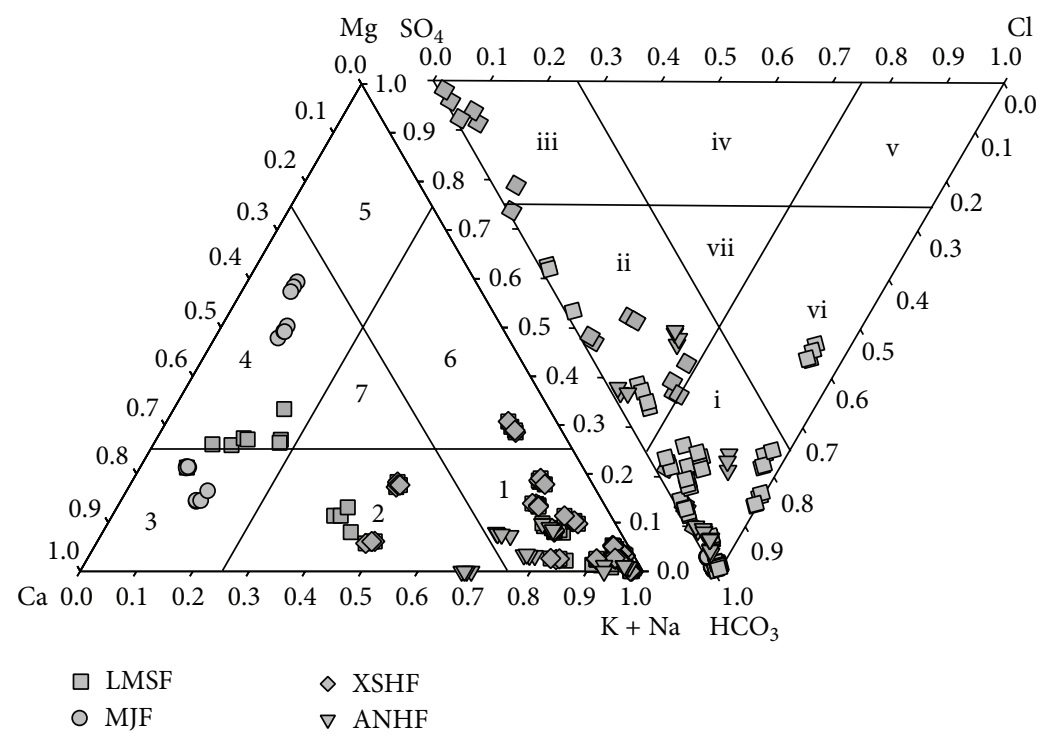

FIGURE 2: Ternary plots of the cation and anion for the waters.

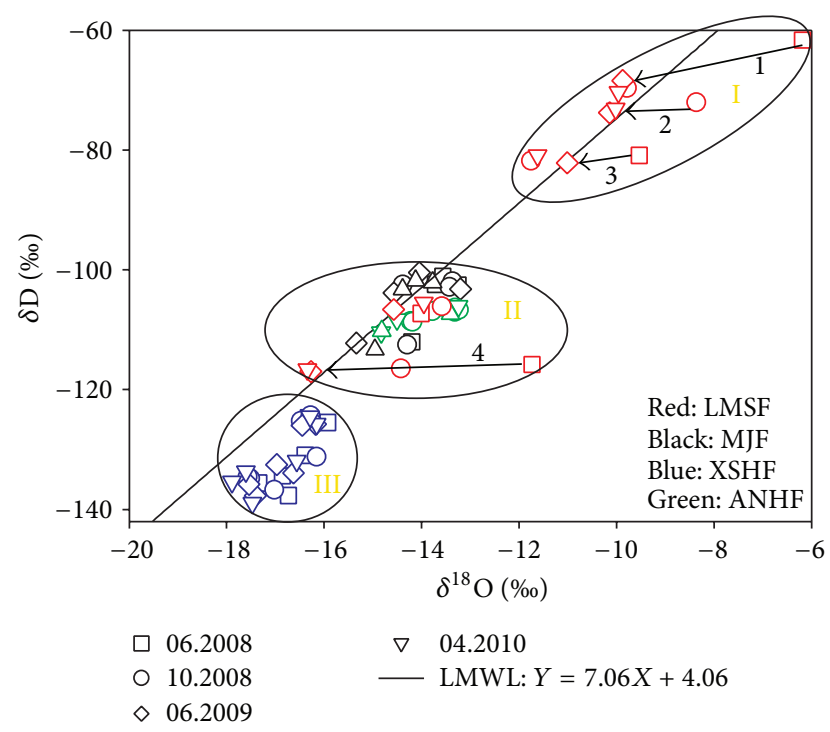

Figure 3: Diagram of $\delta^{18} \mathrm{O}$ versus $\delta \mathrm{D}$ of the waters. LMWL stands for the Local Meteoric Water Line: $\delta \mathrm{D}=7.06 \delta^{18} \mathrm{O}-4.06$.

sites. The anions and cations of the water samples were mainly distributed in blocks $\mathrm{i}$, ii, and iii, indicating that $\mathrm{Na}^{+}, \mathrm{Ca}^{2+}, \mathrm{SO}_{4}{ }^{2-}$, and $\mathrm{HCO}_{3}{ }^{-}$were the main chemical composition for most of the samples. Based on the Shoka Lev's classification method, the water samples were classified into 9 chemical types according to the main chemical composition, which are $\mathrm{Na}(\mathrm{Ca})-\mathrm{HCO}_{3}\left(\mathrm{SO}_{4}\right), \mathrm{Na}(\mathrm{Mg})$ $\mathrm{HCO}_{3}\left(\mathrm{SO}_{4}\right), \mathrm{Ca}(\mathrm{Na})-\mathrm{HCO}_{3}\left(\mathrm{SO}_{4}\right), \mathrm{Mg}(\mathrm{Ca})-\mathrm{SO}_{4}, \mathrm{Ca}(\mathrm{Mg})-$ $\mathrm{SO}_{4}, \mathrm{Ca}(\mathrm{Mg})-\mathrm{HCO}_{3}, \mathrm{Mg}(\mathrm{Ca})-\mathrm{HCO}_{3}, \mathrm{Na}-\mathrm{Cl}\left(\mathrm{HCO}_{3}\right)$, and $\mathrm{Ca}(\mathrm{Na})-\mathrm{SO}_{4}\left(\mathrm{HCO}_{3}\right)$ (Table 1$)$. The cations of the samples of the springs nos. 1-5 occur in the LMSF zone were mainly distributed in the blocks 1,2 , and 4 , and the anions were distributed in the blocks $\mathrm{i}$ and ii, which together formed 4 chemical types of $\mathrm{Na}(\mathrm{Ca})-\mathrm{HCO}_{3}\left(\mathrm{SO}_{4}\right), \mathrm{Ca}(\mathrm{Na})-\mathrm{HCO}_{3}\left(\mathrm{SO}_{4}\right)$, $\mathrm{Mg}(\mathrm{Ca})-\mathrm{SO}_{4}$, and $\mathrm{Ca}(\mathrm{Mg})-\mathrm{SO}_{4}$. The cations of the samples of the springs nos. 6-9 occur in the MJF zone were mainly distributed in the blocks 3 and 4, the anions were distributed in the block $\mathrm{i}$, and the chemical types for the samples were $\mathrm{Ca}(\mathrm{Mg})-\mathrm{HCO}_{3}$ and $\mathrm{Mg}(\mathrm{Ca})-\mathrm{HCO}_{3}$. Both of the cations and anions of the samples of the springs nos. 26-32 occur in the ANHF zone were distributed in the blocks i-ii and 12 , these samples have the similar chemical type of $\mathrm{Na}(\mathrm{Ca})$ $\mathrm{HCO}_{3}\left(\mathrm{SO}_{4}\right)$. Half of the samples including the samples of the springs nos. 10-25 occur in the XSHF zone, the cations of these samples were distributed in the blocks 1,2 , and 5 , with anions in the blocks $\mathrm{i}$, ii, iii, and vi, and the chemical types were $\mathrm{Na}(\mathrm{Ca})-\mathrm{HCO}_{3}\left(\mathrm{SO}_{4}\right), \mathrm{Na}(\mathrm{Mg})-\mathrm{HCO}_{3}\left(\mathrm{SO}_{4}\right), \mathrm{Na}$ $\mathrm{Cl}\left(\mathrm{HCO}_{3}\right)$, and $\mathrm{Ca}(\mathrm{Na})-\mathrm{SO}_{4}\left(\mathrm{HCO}_{3}\right)$.

\subsubsection{The Origins}

(1) $\delta D$ and $\delta^{18} O$. The values of $\delta^{18} \mathrm{O}$ and $\delta \mathrm{D}$ of the 32 springs were plotted along the local meteoric water line (LMWL: $\delta \mathrm{D}=7.06 \delta^{18} \mathrm{O}+4.06$ ) with different extent shifts from the LMWL (Figure 3), which indicated that the spring waters were mainly originated from meteoric water and with different extent alteration. The values of $\delta^{18} \mathrm{O}$ and $\delta \mathrm{D}$ were plotted in three regions, the region I includes the samples of the springs no.1-3, with values of $\delta \mathrm{D}$ and $\delta^{18} \mathrm{O}$ ranged from $-82.13 \%$ o to $-61.66 \%$ o and $-11.75 \%$ to $-6.18 \%$, the region III includes all the samples from the XSHF zone (springs nos. 10-25), with values of $\delta \mathrm{D}$ and $\delta^{18} \mathrm{O}$ between $-141.98 \%$ and $-78.77 \%$, $-18.84 \%$ and $-10.04 \%$, respectively, and the others in the region $\mathrm{II}$, with the values of $\delta \mathrm{D}$ and $\delta^{18} \mathrm{O}$ ranging from $-116.81 \%$ o to $-96.10 \%$ and $-16.34 \%$ o to $-11.64 \%$ o (Table 1 ). The values of $\delta \mathrm{D}$ and $\delta^{18} \mathrm{O}$ of the springs nos.10-25 from 
the higher mountain area were more negative, while those of the springs nos. 1-3 collected in the lower altitude region were less negative, which is constant with the previous results [32].

(2) $\mathrm{Na}(\mathrm{Ca})-\mathrm{HCO}_{3}\left(\mathrm{SO}_{4}\right), \mathrm{Na}(\mathrm{Mg})-\mathrm{HCO}_{3}\left(\mathrm{SO}_{4}\right)$, and $\mathrm{Na}$ $\mathrm{Cl}\left(\mathrm{HCO}_{3}\right)$ Waters. The water samples of the springs nos. 4-5, 10-23 and 25-32 were belong to these types (Table 1). The springs nos. 4-5, 13-23 and 25 occur in granite, while the springs nos. 10-11 in Late Triassic clastic rock interbeded with volcanic rocks. The spring no. 12 is found in Late Permian volcanic tuff, while the spring no. 26 in Sinian pyroclastic rock. The spring nos. 27-29 and 31 are found in Cretaceous clastic rock, the spring no. 30 in Early Triassic sandstone, and the spring no. 32 in Paleozoic mixed layer (Figure 1). The springs nos. 4-5, 10-23 and 25-32 occur in the rocks enriched in feldspar resulting in similar higher concentrations of $\mathrm{Na}^{+}$ and $\mathrm{HCO}_{3}{ }^{-}$because of rock-water interaction. In addition, the samples from the springs nos. 5, 19, 23, and 32 were characterized by the similar concentrations of $\mathrm{Ca}^{2+}, \mathrm{Mg}^{2+}$, and $\mathrm{SO}_{4}{ }^{2-}$ (Table 1), which should be attributed to the water-rock interactions between groundwater and Devonian carbonate (Figure 1). $\mathrm{Cl}^{-}$is known to be conservative and derive from the deep earth mainly $[33,34]$. The chemical type for the samples from the spring no. 16 was $\mathrm{Na}-\mathrm{Cl}$ $\left(\mathrm{HCO}_{3}\right)$, with the $\mathrm{Cl}^{-}$concentration as $328.54 \mathrm{mg} / \mathrm{l}$ (Table 1 ), which suggested the input of deep fluid. Meanwhile, the high ${ }^{3} \mathrm{He} /{ }^{4} \mathrm{He}$ ratio (between 1.43 and 3.73RA, $\mathrm{RA}=1.39 \times 10^{-6}$ ) [30] together with the high temperatures (between $80.0^{\circ} \mathrm{C}$ and $70.2^{\circ} \mathrm{C}$ ) also are the evidences for the upwelling of the deep-earth fluids into the spring (Table 1 ).

(3) $\mathrm{Ca}(\mathrm{Na})-\mathrm{HCO}_{3}\left(\mathrm{SO}_{4}\right), \mathrm{Ca}(\mathrm{Mg})-\mathrm{HCO}_{3}, \mathrm{Mg}(\mathrm{Ca})-\mathrm{HCO}_{3}$, and $\mathrm{Ca}(\mathrm{Na})-\mathrm{SO}_{4}\left(\mathrm{HCO}_{3}\right)$ Waters. These included the samples from the springs nos.1, 6-9, and 24 (Table 1). The spring no. 1 occurs in Jurassic carbonate interbedded with sandstone. The springs nos. 6 and 9 occur in Late Triassic clastic rock interbedded with carbonate. The springs nos. 7 and 8 occur in Middle Triassic clastic rock interbedded with carbonate, and the spring no. 24 is found in Carboniferous carbonate (Figure 1). The springs nos. 1, 6-9, and 24 occur in strata enriched in carbonate, so that the main components of the waters were $\mathrm{Ca}^{2+}, \mathrm{Mg}^{2+}$ and $\mathrm{HCO}_{3}{ }^{-}$because of the interaction between the groundwater and carbonate. The samples of the springs nos. 8 and 9 have the same chemical type of $\mathrm{Mg}(\mathrm{Ca})-\mathrm{HCO}_{3}$, and similar $\mathrm{Ca} / \mathrm{Mg}$ ratios $(0.54$ and 0.86 , Table 1), which can be attributed to the dissolution of calcite combined with the low temperatures of the springs nos. 8 and $9\left(8.8^{\circ} \mathrm{C}\right.$ and $9.0^{\circ} \mathrm{C}$ respectively) (Table 1$)$.

(4) $\mathrm{Mg}(\mathrm{Ca})-\mathrm{SO}_{4}$ and $\mathrm{Ca}(\mathrm{Mg})-\mathrm{SO}_{4}$ Waters. The springs nos. 2 and 3 occur in Devonian to Silurian pyrite-bearing sale and marlite (Figure 1), from which the samples had higher $\mathrm{SO}_{4}{ }^{2-}$ concentration $(878.08 \mathrm{mg} / \mathrm{L}$ and $812.50 \mathrm{mg} / \mathrm{L}$, resp.) and TDS $(1571.81 \mathrm{mg} / \mathrm{L}$ and $1195.08 \mathrm{mg} / \mathrm{L}$, resp.), with the chemical types of $\mathrm{Mg}(\mathrm{Ca})-\mathrm{SO}_{4}$ and $\mathrm{Ca}(\mathrm{Mg})-\mathrm{SO}_{4}$ (Table 1 ), indicating interaction between carbonate and groundwater enhanced by the sulfate from the oxidation of pyrite [35].

\subsection{Chemical Variations of the Spring Waters Associated with Seismic Activities}

5.2.1. Temporal Variations. The hydrochemical data of the water samples showed evident trend of temporal variations.

The geochemical parameters of the samples nos. 1, 3-5 from the LMSF zone and the samples nos. 15 and 20 from the XSHF zone varriedby more than $20 \%$ one month after the Wenchuan earthquake, and similar variations happened after October 2008. The concentrations of $\mathrm{Na}^{+}, \mathrm{Ca}^{2+}, \mathrm{Cl}^{-}$, $\mathrm{SO}_{4}{ }^{2-}$, and TDS of the sample of the spring no. 1 decreased by $42 \%, 39 \%, 53 \%, 31 \%$, and $35 \%$, respectively; for the sample number 2, the decreasing amplitudes for the concentrations of $\mathrm{Na}^{+}, \mathrm{Mg}^{2+}, \mathrm{Ca}^{2+}, \mathrm{Cl}^{-}, \mathrm{SO}_{4}{ }^{2-}$, and TDS were $23 \%, 45 \%$, $25 \%, 38 \%, 22 \%$, and $33 \%$, separately. The concentrations of $\mathrm{Mg}^{2+}, \mathrm{Ca}^{2+}, \mathrm{HCO}_{3}{ }^{-}$, and TDS of the sample from the spring no. 3 decreased by $33 \%, 42 \%, 95 \%$, and $35 \%$, respectively. The concentrations of $\mathrm{Na}^{+}, \mathrm{HCO}_{3}{ }^{-}$, and TDS of the sample of the spring no. 4 decreased by $67 \%, 33 \%$ and $57 \%$, respectively. For the sample of the spring no. 5, the concentrations of $\mathrm{Na}^{+}, \mathrm{HCO}_{3}{ }^{-}$and TDS decreased by $25 \%, 41 \%$, and $26 \%$, respectively. The concentrations of $\mathrm{Na}^{+}$and $\mathrm{SO}_{4}{ }^{2-}$ of sample of the spring no. 20 decreased by $28 \%$ and $26 \%$, respectively. For the sample of the spring no. 15, however the concentrations of $\mathrm{Na}^{+}, \mathrm{HCO}_{3}{ }^{-}$and TDS increased in 17 April 2010, with the amplitudes of 53\%, 38\%, and 38\%, respectively. Meanwhile, the $\delta^{18} \mathrm{O}-\delta \mathrm{D}$ plots of the samples from the springs nos.1, 3, and 4 approached the LMWL (Local Meteoric Line) after sizeable shift in June 2008, and the similar variation happened for the spring no. 2 after October 2008 (Figure 3), which indicated gradual input decrease of deep-earth fluids that formed by water-rock reaction after the Wenchuan earthquake

The supplement of deep water characterized by higher mineralization and enriched in $\delta^{18} \mathrm{O}$ is considered as a main factor for controlling pre- and co-seismic geochemical variations of the groundwater and springs $[2,6,7,11,13,14,16$, $36,37]$. The Coulomb stress in the middle-north segment of the LMSF zone, the southeast segment of the XSHF zone, and the south segment of the MJF zone had been enhanced, which resulted in the Wenchuan $M_{S} 8.0$ earthquake $[38,39]$, and the geochemical variations of the samples from the springs nos. 1-5 and 20. Meanwhile, the input decrease of deepearth water during the sampling period in which seismic activity decreased gradually. 747 aftershocks with $M_{S}$ higher than 4.0 occurred in the three fault zones, and most of which (including all the 12 events with amplitude ranged from 6.0 to 6.4) occurred before September 10, 2008 (China Earthquake Network Center, Figure 1). As the aftershock activities became weak, the TDS values of the samples from the springs nos. 1-5 and 20 decreased gradually to the normal value (Figure 4), indicating the supplement decrease of the deep-earth fluid as the Coulomb stress being released after the events as indicated by the data of oxygen and hydrogen isotope compositions (Figure 3).

Notably, the concentrations of $\mathrm{Na}^{+}, \mathrm{HCO}_{3}{ }^{-}$, and TDS of the sample of the spring no. 15 increased by $53 \%, 38 \%$, and 38\% on April 17, 2010 (Figure 4), which was closely related to 


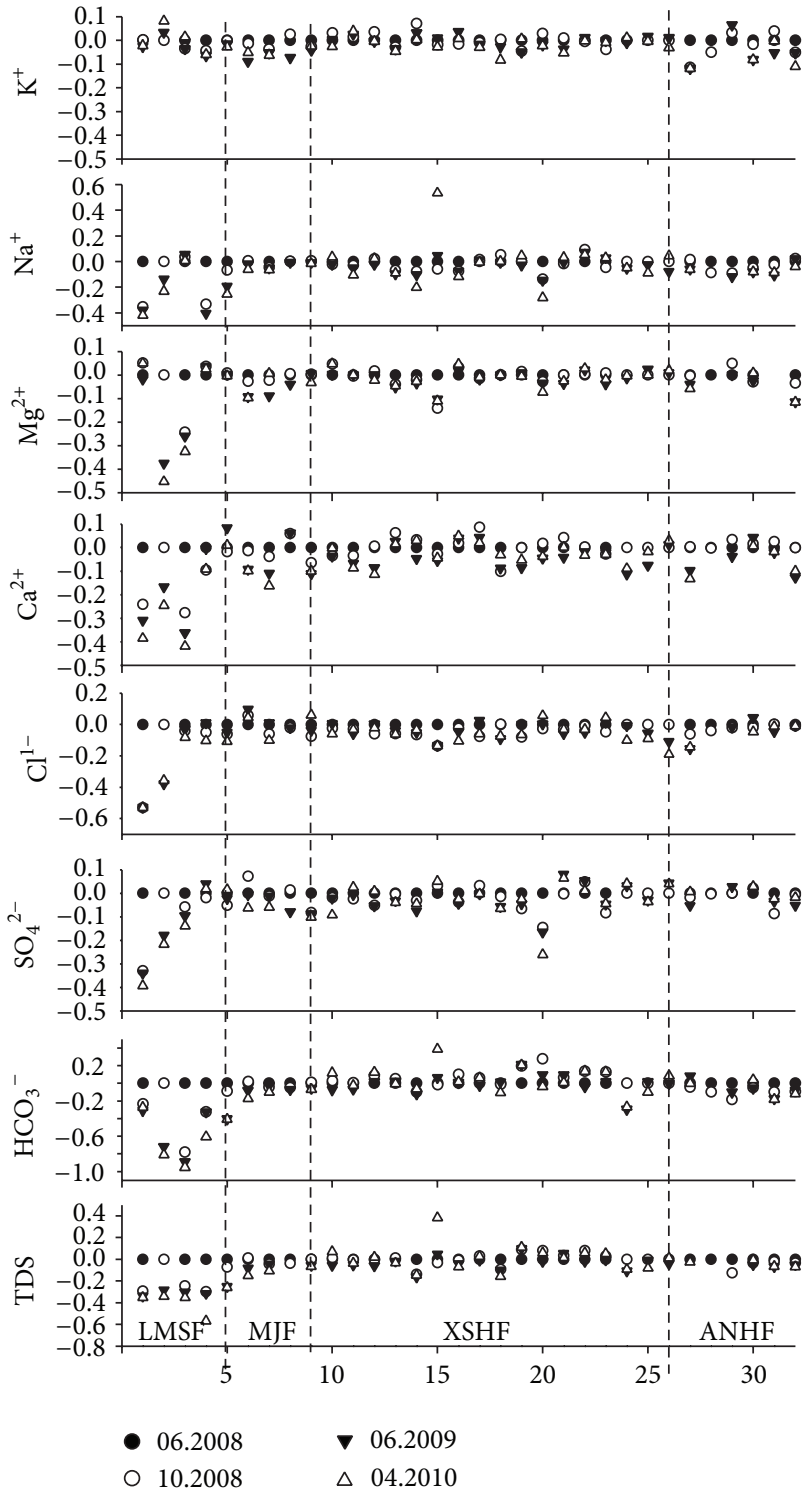

FIGURE 4: Temporal variations of the geochemical parameters of the 32 hot spring waters after the Wenchuan earthquake. The abscissas indicate the numbers of the samples and the ordinates indicate the ratios of each batch of samples with the first batch of samples.

the 28 April 2010 an $M_{S} 5.4$ aftershock 15 kilometers epicenter distance to the spring no. 15 (Figure 1). Therefore, it can be infered that the hydrogeochemical variations of the spring no. 15 might be the short-term hydrogeochemical precursors for the $M_{S} 5.4$ event.

The geochemical parameters of the samples from the springs nos. 16-17 and 19 about 200 kilometers showed evident increase trend before the Wenchuan earthquake [20, $24,25]$. The $\mathrm{K}^{+}$concentrations of the samples of the springs nos. $16-17$ and 19 increased by $19.3 \%$ to $54.4 \%$ before the main shock, and rapidly decreased to the normal values after the main shock. The concentrations of $\mathrm{SO}_{4}{ }^{2-}$ for the samples from the springs nos. 16 and 19 increased by $32.0 \%$ and $59.6 \%$ respectively before the earthquake, and then dropped

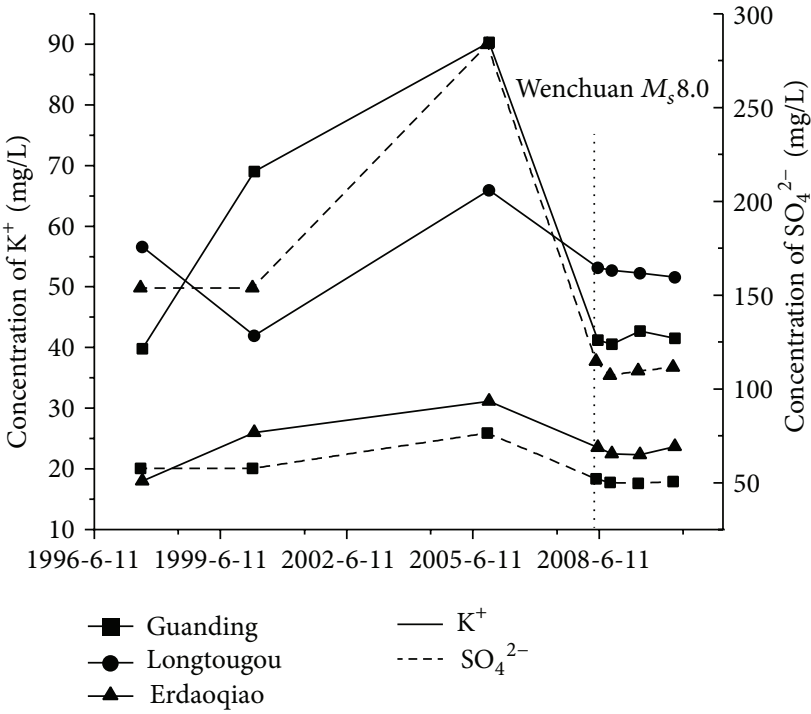

FIGURE 5: Temporal variations of concentration of $\mathrm{K}^{+}$and $\mathrm{SO}_{4}{ }^{2-}$. Black squares: waters collected from the Guanding spring; black cycles: waters collected from the Longtougou spring; black triangles: waters collected from the Erdaoqiao spring; the dashed vertical line: the time of the occurrence of the Wenchuan earthquake.

to the normal value after the main shock (Figure 5). The springs nos. 16-17 and 19 occur in the intersection of the LMSF, XSHF and ANHF zones where the extrusion stress increased yearly from 2004 to 2007 before the Wenchuan earthquake $[40,41]$. Therefore, the increase of $\mathrm{K}^{+}$and $\mathrm{SO}_{4}{ }^{2-}$ concentrations for the samples of the springs nos.16-17 and 19 could be attributed to the more supplement of the deep fluids with higher concentrations of $\mathrm{K}^{+}$and $\mathrm{SO}_{4}{ }^{2-}$ [42], The ${ }^{3} \mathrm{He} /{ }^{4} \mathrm{He}$ ratios of the samples from the springs nos. 1617 and 19 increased before the Wenchuan earthquake, but showed a remarkable drop after the shock, and then became normal indicating the more supplement of mantle-derived fluids before the main shock [30].

5.2.2. Spatial Variations. The geochemical and isotopic compositions of the samples from the springs nos. 1-5 occur in the LMSF zone performed evident variation after the Wenchuan earthquake, with the highest amplitude as $95 \%$ for $\mathrm{HCO}_{3}{ }^{-}$ of the sample from the spring no. 5. However, for the other samples from the other fault zones, just the samples from the springs nos. 15 and 20 presented obvious geochemical variations, with the highest amplitude as $53 \%$ for $\mathrm{Na}^{+}$of the sample from the spring no. 15 (Figure 4). The Wenchuan earthquake happened in the LMSF zone, which enhanced the Coulomb stress of the zone $[38,39]$, and with most of the aftershocks occurred there (Figure 1). For the springs nos. 1-5 occurred in the LMSF zone, the epicenter distances are between 50 and 110 kilometers, which are smaller than those of the hot springs nos. 6-32 (between 190 and $410 \mathrm{~km}$ ). Therefore, the variation of the tectonic stress induced by the Wenchuan earthquake and the aftershocks may resulted in, 
the geochemical and isotopic variations for the springs nos. 1-5 after the Wenchuan earthquake.

\section{Conclusions}

120 water samples of the 32 hot springs in the western Sichuan have been analyzed after the Wenchuan earthquake. The following conclusions can be drawn.

(1) The waters of the 32 springs were mainly derived from meteoric precipitation. Because of the isotopic elevation effect, the $\delta \mathrm{D}$ and $\delta^{18} \mathrm{O}$ of the samples from the higher mountain area were lower, but those of samples from the lower altitude region were higher. all of the analyzed water samples from the 32 springs can be classified into nine chemical types: $\mathrm{Na}(\mathrm{Ca})-\mathrm{HCO}_{3}\left(\mathrm{SO}_{4}\right), \mathrm{Na}(\mathrm{Mg})-\mathrm{HCO}_{3}\left(\mathrm{SO}_{4}\right), \mathrm{Ca}(\mathrm{Na})-$ $\mathrm{HCO}_{3}\left(\mathrm{SO}_{4}\right), \mathrm{Mg}(\mathrm{Ca})-\mathrm{SO}_{4}, \mathrm{Ca}(\mathrm{Mg})-\mathrm{SO}_{4}, \mathrm{Ca}(\mathrm{Mg})-$ $\mathrm{HCO}_{3}, \mathrm{Mg}(\mathrm{Ca})-\mathrm{HCO}_{3}, \mathrm{Na}-\mathrm{Cl}\left(\mathrm{HCO}_{3}\right)$, and $\mathrm{Ca}(\mathrm{Na})-$ $\mathrm{SO}_{4}\left(\mathrm{HCO}_{3}\right)$, which were mainly controlled by waterrock interaction and the input of deep fluid.

(2) The concentrations of $\mathrm{K}^{+}$and $\mathrm{SO}_{4}{ }^{2-}$ of the samples of the springs nos.16-17 and 19 in the intersection of LMSF, XSHF, and ANHF varied evidently, with the amplitude ranging from $19.3 \%$ to $59.6 \%$ before and after the Wenchuan earthquake which may be attributed to the interfusion of the deep fluids with high $\mathrm{K}^{+}$and $\mathrm{SO}_{4}{ }^{2-}$ induced by the increased tectonic stress.

(3) The hydrogeochemical variations of the springs closer to the epicenter performed more obviously after the Wenchuan earthquake. As the aftershock activities became weak, the geochemical parameters of the samples from the springs nos. 1-5, 15, and 20 located in the regions where the tectonic stress was enhanced before the Wenchuan $M_{S} 8.0$ earthquake decreased by more than $20 \%$, and with the $\delta^{18} \mathrm{O}$ the LMWL, which may be related to the change of tectonic stress when the aftershock activities became weak.

\section{Conflict of Interests}

The authors declare that there is no conflict of interests regarding the publication of this paper.

\section{Acknowledgments}

The authors are grateful to the Seismological Bureau of Sichuan province and Professor Fang Du for helping in the field work. The authors sincerely thank the editor and reviewers for their valuable comments and grammar edits in improving the paper. This research was supported by the National Science and Technology Support Program (the characteristics of gas geochemistry of Longmenshan faults, WFSD-10), the Basic Science Research Plan of the Institute of Earthquake Science, China Earthquake Administration (The fluid geochemical survey of the mud volcanoes in the North of the Tianshan Mountain, Xinjiang Uygur Autonomous
Region 02132417), and the Basic Science Research Plan of the Institute of Earthquake Science, China Earthquake Administration (02132417).

\section{References}

[1] A. Dadomo, M. Lemmi, G. Martinelli, M. Menichetti, and L. Telesca, "Springwater continuous monitoring in the L'Aquila area in concomitance with the April 2009 seismic swarm in central Italy: constraining factors to possible deep-seated fluid emissions," Chemical Geology, vol. 339, pp. 169-176.

[2] R. Favara, F. Italiano, and G. Martinelli, "Earthquake-induced chemical changes in the thermal waters of the Umbria region during the 1997-1998 seismic swarm," Terra Nova, vol. 13, no. 3, pp. 227-233, 2001.

[3] C.-Y. King, N. Koizumi, and Y. Kitagawa, "Hydrogeochemical anomalies and the 1995 Kobe earthquake," Science, vol. 269, no. 5220, pp. 38-39, 1995.

[4] F. Quattrocchi, R. Favara, G. Capasso et al., "Thermal anomalies and fluid geochemistry framework in occurrence of the 2000-2001 Nizza Monferrate seismic sequence (northern Italy): episodic changes in the fault zone heat flow or chemical mixing phenomena?" Natural Hazards and Earth System Science, vol. 3, no. 3-4, pp. 269-277, 2003.

[5] D. V. Reddy, P. Nagabhushanam, and B. S. Sukhija, "Earthquake (M 5.1) induced hydrogeochemical and $\delta^{18} \mathrm{O}$ changes: Validation of aquifer breaching-mixing model in Koyna, India," Geophysical Journal International, vol. 184, no. 1, pp. 359-370, 2011.

[6] S.-R. Song, Y.-L. Chen, C.-M. Liu et al., "Hydrochemical changes in spring waters in Taiwan: implications for evaluating sites for earthquake precursory monitoring," Terrestrial, Atmospheric and Oceanic Sciences, vol. 16, no. 4, pp. 745-762, 2005.

[7] F. Italiano, P. Bonfanti, L. Pizzino, and F. Quattrocchi, "Geochemistry of fluids discharged over the seismic area of the Southern Apennines (Calabria region, Southern Italy): implications for Fluid-Fault relationships," Applied Geochemistry, vol. 25 , no. 4, pp. 540-554, 2010.

[8] S. İnan, W. P. Balderer, F. Leuenberger-West, H. Yakan, A. Özvan, and F. T. Freund, "Springwater chemical anomalies prior to the $M w=7.2$ Van earthquake (Turkey)," Geochemical Journal, vol. 46, no. 1, pp. el1-e16, 2012.

[9] M. Malakootian and J. Nouri, "Chemical variations of ground water affected by the earthquake in bam region," International Journal of Environmental Research, vol. 4, no. 3, pp. 443-454, 2010.

[10] D. Thomas, "Geochemical precursors to seismic activity," Pure and Applied Geophysics, vol. 126, no. 2-4, pp. 241-266, 1988.

[11] H. Woith, R. Wang, U. Maiwald, A. Pekdeger, and J. Zschau, "On the origin of geochemical anomalies in groundwaters induced by the Adana 1998 earthquake," Chemical Geology, vol. 339, pp. 177-186, 2013.

[12] X. Zhou, J. Du, Z. Chen et al., "Geochemistry of soil gas in the seismic fault zone produced by the Wenchuan $M_{S} 8.0$ earthquake, southwestern China," Geochemical Transactions, vol. 11, article 5, 2010.

[13] M. S. Miller, A. Allam, T. W. Becker, J. F. Dileo, and J. Wookey, "Constraints on the geodynamic evolution of the westernmost Mediterranean and northwestern Africa from shear wave splitting analysis," Earth and Planetary Science Letters, vol. 375, pp. 234-243, 2013. 
[14] C.-Y. Wang, M. Manga, C.-H. Wang, and C.-H. Chen, "Transient change in groundwater temperature after earthquakes," Geology, vol. 40, no. 2, pp. 119-122, 2012.

[15] G. Etiope, M. Calcara, and F. Quattrocchi, "Seismogeochemical algorithms for earthquake prediction: an overview," Annali di Geofisica, vol. 40, no. 6, pp. 1483-1492, 1997.

[16] J. Du, K. Amita, S. Ohsawa, Y. Zhang, C. Kang, and M. Yamada, "Experimental evidence on formation of imminent and short-term hydrochemical precursors for earthquakes," Applied Geochemistry, vol. 25, no. 4, pp. 586-592, 2010.

[17] Y. Cao, H. Li, Z. Liu, D. Yuan, and L. Shen, "Comparison of geochemical features of warm springs between Chongqing and Kangding," Carsologica Sinica, vol. 25, no. 2, pp. 113-121, 2006.

[18] S. Jia, X. Li, and Y. Hu, "The hydrogeochemistry problems of the shallow heat reservoir in Zhuhai thermal spring," Journal of Chengdu University of Technology, vol. 24, no. 1, pp. 78-84, 1997.

[19] L. L. Luo, "The primary study of distribution and genesis of the springs in western Sichuan province," Journal of Chongqing Teachers College, vol. 11, no. 2, pp. 39-47, 1994.

[20] L. Zaihua, Y. Daoxian, H. Shiyi, Z. Meiliang, and Z. Jiagui, "Geochemical features of the geothermal $\mathrm{CO}_{2}$-water-carbonate rock system and analysis on its $\mathrm{CO}_{2}$ sources," Science in China D: Earth Sciences, vol. 43, no. 6, pp. 569-576, 2000.

[21] H. Li, G. Yin, J. Yang, and X. Fan, "Isotopic hydrogeochemical characteristics of water bodies in Munigou, Sichuan," Acta Geoscientica Sinica, vol. 26, no. 3, pp. 255-258, 2005.

[22] M. Liu, "A study on genesis of Hongge hot spring in Yanbian, Sichuan Province," Coal Geology of China, vol. 20, no. 3, pp. 4549, 2008.

[23] R. Q. Lu, D. Y. Wang, Y. H. Zuo, Q. L. Wu, Y. W. Liu, and X. Y. $\mathrm{Li}$, "Remote-sensing geological features of thermal spring in the Kaka Gulley, Songpan, Sichuan," Acta Geologica Sinica, vol. 28, no. 1, pp. 73-75, 2008.

[24] L. C. Shen, The study of deep source $\mathrm{CO}_{2}$ degasification and carbon cycle in the southwest of China [Ph.D. dissertation], Southwest University, 2007.

[25] J. G. Zhang and H. T. Hu, "Quantification research of $\mathrm{CO}_{2}$ outgassing from hot springs along Xianshuihe fault zone, Sichuan," Hydrogeology and Engineering Geology, vol. 27, no. 3, pp. 19-21, 2000.

[26] B. C. Burchfiel, L. H. Royden, R. D. van der Hilst et al., "A geological and geophysical context for the Wenchuan earthquake of 12 May 2008, Sichuan, People's Republic of China," GSA Today, vol. 18, no. 7, pp. 4-11, 2008.

[27] Z. L. Li, Z. H. Luo, Y. L. Chen, and J. X. Zhao, "Geochronological and geochemical characteristics of Kangding metamorphosed intrusions," Acta Geoscientica Sinica, vol. 26, no. 9, pp. 87-89, 2005.

[28] S. Wu, "The discovery and significance of ductile shear zones in pengguan complex granite mass of Longmenshan mountains," Journal Mineral Petrology, vol. 13, no. 2, pp. 71-77, 1993.

[29] Y. J. Zhao, C. Yuan, M. F. Zhou, D. P. Yan, X. P. Long, and K. D. Cai, "Post-orogenic extension of Songpan-Garz(e)orogen in Early Jurassic: constraints from Niuxingou monzodiorite and Siguniangshan A-type granite of western Sichuan, China," Geochimica, vol. 36, no. 2, pp. 139-152, 2007.

[30] X. C. Zhou, Gas geochemistry in western Sichuan related to 12 May 2008 Wenchuan $M_{s} 8.0$ earthquake [Ph.D. dissertation], University of Science and Technology of China, 2011.

[31] X.-W. Xu, X.-Z. Wen, J.-Q. Ye et al., "The $M_{S} 8.0$ Wenchuan earthquake surface ruptures and its seismogenic structure," Seismology and Geology, vol. 30, no. 3, pp. 597-629, 2008.
[32] C. P. Chamberlain and M. A. Poage, "Reconstructing the paleotopography of mountain belts from the isotopic composition of authigenic minerals," Geology, vol. 28, no. 2, pp. 115-118, 2000.

[33] J. Du, C. Liu, B. Fu et al., "Variations of geothermometry and chemical-isotopic compositions of hot spring fluids in the Rehai geothermal field, southwestern China," Journal of Volcanology and Geothermal Research, vol. 142, no. 3-4, pp. 243-261, 2005.

[34] L. Shevenell and F. Goff, "Evolution of hydrothermal waters at Mount St. Helens, Washington, USA," Journal of Volcanology and Geothermal Research, vol. 69, no. 1-2, pp. 73-94, 1995.

[35] M. Floyd, M. A. Czerewko, J. C. Cripps, and D. A. Spears, "Pyrite oxidation in Lower Lias Clay at concrete highway structures affected by thaumasite, Gloucestershire, UK," Cement and Concrete Composites, vol. 25, no. 8, pp. 1015-1024, 2003.

[36] A. Charmoille, O. Fabbri, J. Mudry, Y. Guglielmi, and C. Bertrand, "Post-seismic permeability change in a shallow fractured aquifer following a ML 5.1 earthquake (Fourbanne karst aquifer, Jura outermost thrust unit, eastern France)," Geophysical Research Letters, vol. 32, no. 18, Article ID L18406, pp. 1-5, 2005.

[37] C.-Y. King, W. Zhang, and Z. Zhang, "Earthquake-induced groundwater and gas changes," Pure and Applied Geophysics, vol. 163, no. 4, pp. 633-645, 2006.

[38] B. Shan, X. Xiong, Y. Zheng, and F. Diao, "Stress changes on major faults caused by $M w 7.9$ Wenchuan earthquake, May 12, 2008," Science in China D: Earth Sciences, vol. 52, no. 5, pp. 593601, 2009.

[39] C. D. Xie, Y. Q. Zhu, X. L. Lei, H. Y. Yu, and X. L. Hu, "Pattern of stress change and its effect on seismicity rate caused by $M_{S}$ 8.0 Wenchuan earthquake," Science China Earth Sciences, vol. 53, no. 9, pp. 1260-1270, 2010.

[40] G. Luo and M. Liu, "Stress evolution and fault interactions before and after the 2008 Great Wenchuan earthquake," Tectonophysics, vol. 491, no. 1-4, pp. 127-140, 2010.

[41] X. Zhang, D. Cui, and F. Jing, "Inversion of seismic parameters of the Wenchuan earthquake and analysis on variation of its Coulomb stress based on GPS observation," Journal of Seismological Research, vol. 32, no. 4, pp. 351-356, 2009.

[42] Y. Fang, Z. S. Jiang, Y. L. Yang, G. H. Gu, and Y. Q. Wu, “Deformation characteristics of Southern segment of Xianshuihe fault before and after Wenchuan $M_{S} 8.0$ earthqauke," Journal of Geodesy and Geodynamics, vol. 30, no. 3, pp. 22-27, 2010. 

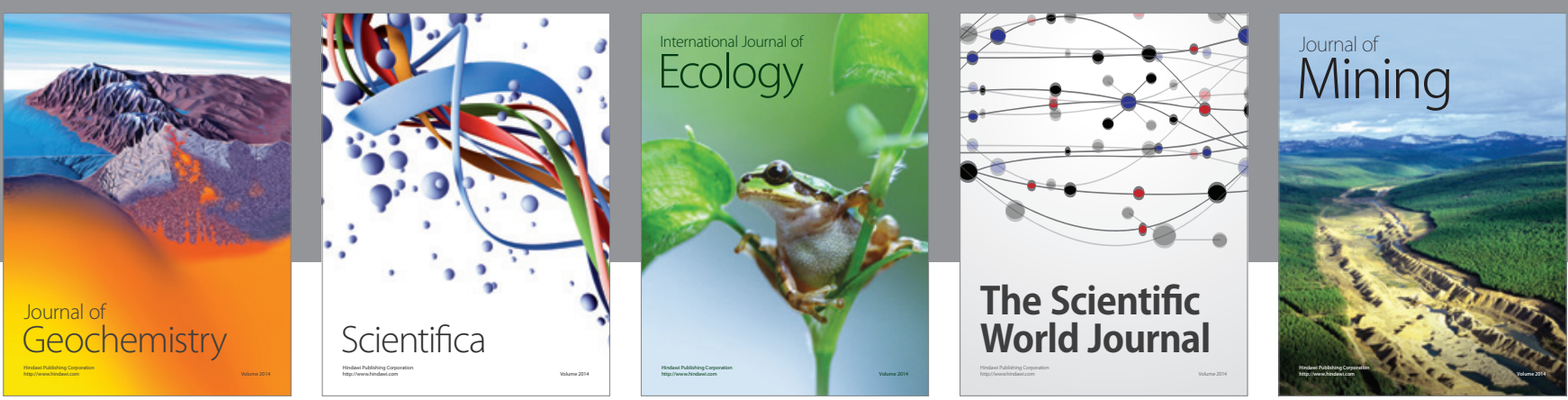

The Scientific World Journal
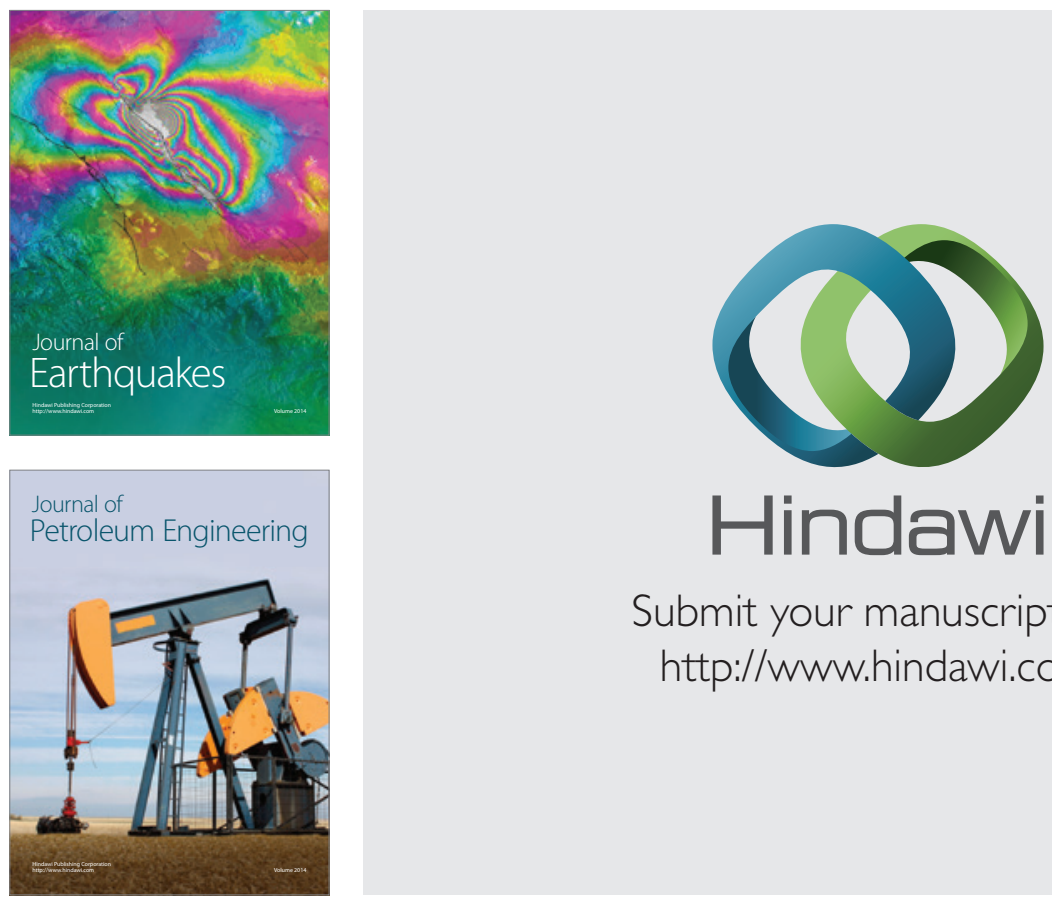

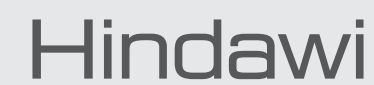

Submit your manuscripts at

http://www.hindawi.com
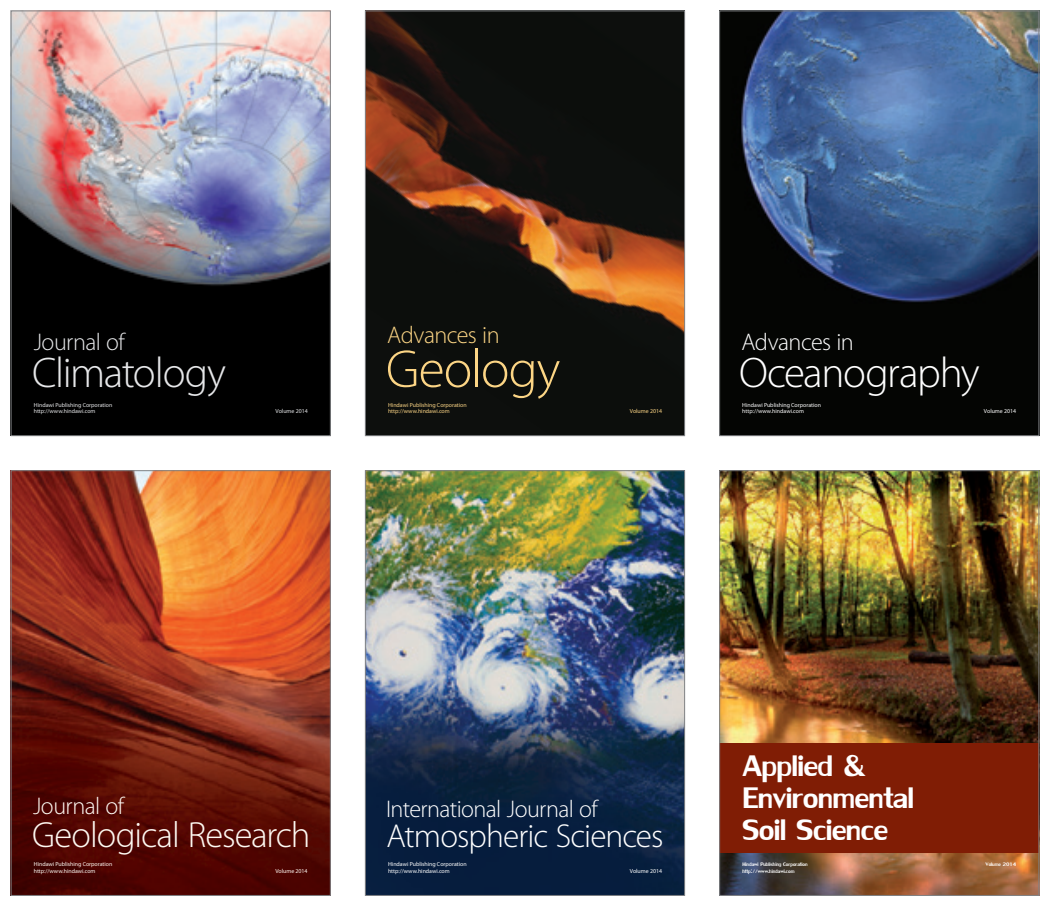
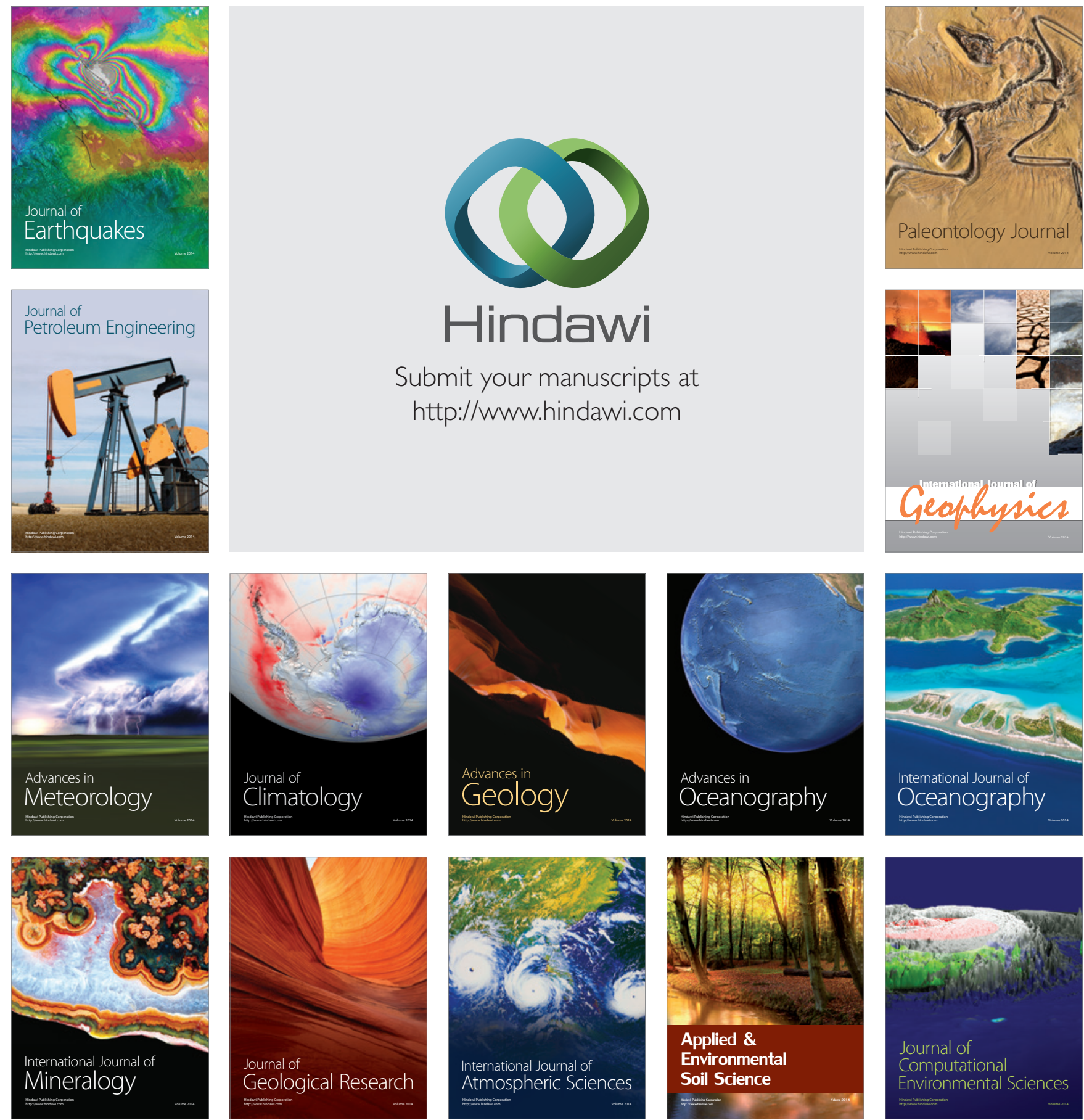